(c) American Dairy Science Association, 2003.

\title{
Effects of Feeding Intensity During the Dry Period. 1. Feed Intake, Body Weight, and Milk Production
}

\author{
S. Agenäs*, E. Burstedt*, and K. Holtenius*† \\ *Department of Animal Nutrition and Management, Swedish University of Agricultural Sciences, \\ SE-750 07 Uppsala, Sweden \\ †Department of Ruminant Medicine and Veterinary Epidemiology, \\ Swedish University of Agricultural Sciences, \\ SE-750 07 Uppsala, Sweden
}

\section{ABSTRACT}

The objective of this experiment was to study dry matter intake (DMI), body condition, milk yield, and milk composition in cows with different body condition at the time of parturition. Twenty four multiparous cows with genetic merit for high or low milk fat content were assigned to one of three diets during the dry period. The treatments consisted of 6,9 , or $14.5 \mathrm{~kg}$ dry matter of a total mixed ration providing 71, 106, or 177 $\mathrm{MJ} / \mathrm{d}$ of metabolizable energy and are referred to as low (L), medium (M), and high $(\mathrm{H})$ dry period rations, respectively. These diets were introduced when the cows were dried off from the previous lactation, at least 8 wk before expected parturition. After parturition all cows were fed another total mixed ration ad libitum. The dietary treatments generated differences between the groups in body weight as well as in body condition score at parturition. There were no differences in DMI in early lactation, but during wk 6 to $12 \mathrm{DMI}$ was lower among $\mathrm{H}$ cows, which was linked to a prolonged negative energy balance in this group. The milk yield was $38.5 \pm 0.8 \mathrm{~kg}$ of energy-corrected milk the first $4 \mathrm{wk}$ postpartum and did not differ between treatments or selection lines. Body weight loss mainly occurred in lactation wk 1 to 4 and was greatest in $\mathrm{H}$ cows. The mobilization of body tissues was reflected in a higher milk fat content of $\mathrm{C}_{18: 0}$ for the $\mathrm{H}$ cows during wk 1 to 4. There were no marked effects of treatments on milk fat content or milk protein content, which indicates that cows in early lactation have a potential to compensate for low nutrient intake during the dry period if they are offered a high-quality diet. The observed differences between treatments in DMI wk 6 to 12 could not be explained by differences in milk yield or mobilization of body tissues. Milk fat content was $4.7 \%$ in cows with

Received March 25, 2002.

Accepted August 9, 2002.

Corresponding author: Sigrid Agenäs; e-mail: Sigrid.Agenas@ huv.slu.se. genetic merit for high milk fat content and $4.2 \%$ in cows with genetic merit for low milk fat content. There was a tendency for higher body weight in cows with genetic merit for low milk fat content throughout the experiment.

(Key words: dry period, dry matter intake, milk production, milk fatty acids)

Abbreviation key: CLA = conjugated linoleic acid, EB = energy balance, $\mathbf{E C M}=$ energy-corrected milk, $\mathbf{H}=$ high dry period ration, $\mathbf{H F I}=$ high fat indexed, $\mathbf{L}=$ low dry period ration, LCFA = long chain fatty acids, LFI = low fat indexed, $\mathbf{M}=$ medium dry period ration, $\mathbf{M E}$ $=$ metabolizable energy, SCFA $=$ short chain fatty acids .

\section{INTRODUCTION}

The ability to store nutrients in body tissues during pregnancy and to use these reserves for milk production for the benefit of the young is a reproductive strategy, which strongly influences the behavior and physiology of mammals. Consequently, the early-lactating cow is prepared to support lactation by utilizing body reserves. However, in modern dairy farming this mechanism is used to an extent that causes health problems for the cow. The majority of production disturbances occur around the transition from gestation to lactation and during the first $2 \mathrm{wk}$ of the lactation (Goff and Horst, 1997).

A common recommendation to dairy farmers is to maximize DMI close to parturition to prepare the cow for a higher feed intake immediately after calving and, in turn, reduce metabolic disorders (Grummer, 1995). On the other hand, a high DMI during the dry period can lead to significant increases in body fat which may depress appetite and thereby cause an increased incidence of health disorders and poor milk production (Rukkwamsuk et al., 1999). There is circumstantial evidence that these negative effects are caused by the extensive degradation of body tissues during the postparturient period (Rukkwamsuk et al., 1999). Relatively few studies have evaluated the effects of feeding during 
the dry period on milk composition. However, higher milk fat concentration in early lactation has been reported as an effect of either ad libitum feeding during the dry period (Holcomb et al., 2001) or high BCS at calving (Chilliard, 1992).

The aim of the present study was to investigate effects of differences in BCS at calving on DMI, BCS, and energy balance (EB) during the following lactation and also on milk production and milk fat composition. Three groups of cows with different BCS at calving were obtained. To avoid confounding effects of differences in energy to protein ratio, different amounts of the same TMR was used for the three groups. Responses were studied in two distinct populations of cows that differ in genetic merit for milk fat content and that previously have been suggested to differ in feed intake capacity (Åkerlind et al., 1999).

\section{MATERIALS AND METHODS}

\section{Animals}

The study was performed on 24 multiparous dairy cows of the Swedish Red and White breed, chosen from an ongoing selection program in the dairy herds at the Swedish University of Agricultural Sciences. In this program the cows are bred with sires that have index for high (HFI) or low (LFI) milk fat percentage but the same amount of energy produced in milk (Jansson, 1993; Åkerlind et al., 1999).

\section{Management and Experimental Design}

The cows were dried off, from the lactation preceding this trial, approximately $10 \mathrm{wk}$ before the predicted date of parturition and introduced to the experimental diets 8 wk before parturition was expected. Four cows from each selection line were allocated to one of three dietary treatments during the dry period. The treatments consisted of flat-line rations of 6,9 , or $14.5 \mathrm{~kg}$ DM, of a dry period TMR mix calculated to provide 71, 106, or $177 \mathrm{MJ}$ of metabolizable energy (ME) per day. The dietary treatments are referred to as low $(\mathbf{L})$, me$\operatorname{dium}(\mathbf{M})$, and high $(\mathbf{H})$ dry period rations, respectively. After parturition all cows were fed another TMR mix ad libitum for $15 \mathrm{wk}$. The dry period TMR was a mixture of $45 \%$ grass-dominated silage, $15 \%$ grass-dominated hay, and $40 \%$ of a standard concentrate (calculated on a DM basis). The lactation TMR was a mix of $40 \%$ grassdominated silage, $5 \%$ grass-dominated hay, and $55 \%$ of the same standard concentrate. The standard concentrate consisted of barley $(33.5 \%)$, oats $(28 \%)$, heat treated rapeseed expeller (12\%), dried molassed sugar beet pulp (10\%), soybean meal (7\%), heat treated rapeseed meal (4\%), brewers grain (4\%), and wheat bran
Table 1. Dry matter content, chemical composition and calculated values for metabolizable energy (ME), AA absorbed in the small intestine (AAT), protein balance in the rumen (PBV), ash, CP, EG-fat, water soluble carbohydrates (WSC), starch, NDF, ADF, calcium, and phosphorus of experimental diets. Values are given on DM basis.

\begin{tabular}{lcc}
\hline & \multicolumn{2}{c}{ Diet } \\
\cline { 2 - 3 } & Dry period $^{1}$ & Lactation $^{2}$ \\
\hline DM, \% & 55.5 & 50.4 \\
ME, MJ/kg & 11.8 & 12.2 \\
AAT, g/kg & 86.7 & 92.2 \\
PBV, g/kg & 21.8 & 26.5 \\
Ash, \% & 6.2 & 6.1 \\
CP, \% & 15.7 & 16.3 \\
Crude fat ${ }^{3}, \%$ & 3.1 & 3.5 \\
WSC, \% & 4.7 & 4.2 \\
Starch $\%$ & 14.6 & 16.5 \\
NDF, \% & 41.7 & 38.7 \\
ADF, \% & 25.5 & 23.6 \\
Calcium, g/kg & 4.4 & 4.0 \\
Phosphorus, g/kg & 3.2 & 3.4
\end{tabular}

${ }^{1}$ Cows that received low or medium rations $(6$ and $9 \mathrm{~kg} \mathrm{DM} / \mathrm{d}$ respectively) of the TMR during the dry period were supplemented with $200 \mathrm{~g}$ or $100 \mathrm{~g}$, respectively, of a commercial mineral feed containing $129 \mathrm{~g} / \mathrm{kg}$ calcium and $135 \mathrm{~g} / \mathrm{kg}$ phosphorus (Kvarnby VM1, Kvarnby, Sweden).

${ }^{2}$ All cows were supplemented with $300 \mathrm{~g} / \mathrm{d}$ of a commercial mineral feed containing $146 \mathrm{~g} / \mathrm{kg}$ calcium and $66 \mathrm{~g} / \mathrm{kg}$ phosphorus (Effekt Normal, Lactamin AB, Sweden) postpartum.

${ }^{3}$ Official Journal of the European Communities (1984).

${ }^{4}$ Sum of starch and maltodextrins.

(1.5\%). Daily rations of TMR were divided into three portions fed at 0500,1400 , and $1800 \mathrm{~h}$, administering 30,30 , and $40 \%$ of the daily ration respectively, and feed refusals were collected once daily. Feed samples were obtained three times a week and pooled into seven samples per mix for chemical analyses. Average chemical compositions of the pooled samples are presented in Table 1.

Body weight was registered weekly. Lactating animals were weighed after the morning milking, and BCS was performed first when cows were dried off from the previous lactation and thereafter: 1,6 , and $12 \mathrm{wk}$ after calving. Body condition scoring was performed on a five grade scale with half point increments, where 1 represents very thin and 5 an obese animal, as described by Gillund et al. (1999).

The cows were housed in individual tie stalls with straw and sawdust bedding throughout the experiment. Drinking water was available in automatic water bowls, and the cows had access to salt licks. Milking was performed in a milking parlor, twice daily, starting at 0515 and $1545 \mathrm{~h}$. The experimental design and all handling of the animals were approved by the Uppsala Local Ethics Committee.

\section{Milk Sampling and Analysis}

Milk yield was recorded daily with FloMaster (Alfa Laval Agri, Sweden). Milk samples were obtained at 
evening and morning milking twice weekly. Milk was stored at $4^{\circ} \mathrm{C}$ until determination of fat, protein, and lactose concentration by infrared spectroscopy (DairyLab2, A7S Foss Electric, Denmark) was performed. Energy-corrected milk (ECM) was calculated (Spörndly, 1999). Samples of morning milk for the determination of milk fatty acid composition were obtained on four occasions evenly distributed for each animal across the first $15 \mathrm{wk}$ of the lactation. These samples were then stored at $-80^{\circ} \mathrm{C}$ until the lipids were extracted, using hexane and isopropanol (Nourooz-Zadeh and Appelquist, 1988), followed by methylation of fatty acids (Sukhija and Palmquist, 1988) and separation with a temperature-programmed GLC (Chrompack, CP-sil 88, $100 \mathrm{~m} \times 0.25 \mathrm{~mm}$ i.d.).

Calculation of EB was performed as the difference between the measured energy intake and energy requirement for maintenance and milk production, according to the Swedish feeding recommendation (Spörndly, 1999).

\section{Statistical Analyses}

Analysis of variance was performed on all data using PROC MIXED in the SAS system (SAS, 1996). Least squares means were compared with comparison-wise error rate after significant $\mathrm{F}$ tests, and least significant difference values were based on calculations with $\mathrm{t}_{0.975}$. The ANOVA of DMI, BW, and milk production were performed on mean values, each representing a 4-wk interval, while analyses of EB, BCS, and milk fatty acid composition were performed on single values. Fixed effects of treatment, selection line, and time and their interactions were included in the model. Furthermore, the time factor was divided into two classes defining data as before or after parturition (period). The model used different variances between subjects for the two period classes and different autoregressive covariance structure for the within subject variations. Nonsignificant interactions were excluded from the model for each parameter tested, except for the interaction between treatment and period which was included to provide least squares means for each treatment. The degrees of freedom were approximated with Satterthwaits method (Model 1).

A two-way analysis of variance was performed to test the effect of treatment and selection line on changes in BW. These analyses were performed on BW change between the beginning and end of the dry period, the week before and the week after parturition, and also on the difference between lactation wk 1 and 12. Furthermore, $t$-tests were performed on these data to test differences between the treatment groups and between the selection lines (Model 2). One animal was excluded from the experiment $6 \mathrm{wk}$ after parturition for reasons not related to the experiment.

\section{Model 1. \\ PROC MIXED; \\ classes T SL time id period; \\ MODEL $=\mathrm{T}$ SL time $\mathrm{T} \times \mathrm{SL} \mathrm{T} \times$ time $\mathrm{SL}$ $\times$ time $/$ DDFM $=$ SAT; \\ REPEATED $/ \mathrm{SUB}=\mathrm{ID}(\mathrm{T} \times \mathrm{SL}) \mathrm{TYPE}=\mathrm{AR}(1)$ GROUP = PERIOD;}

\section{Model 2. \\ PROC MIXED; \\ classes T SL id; \\ MODEL = T SL line;}

T: dietary treatment (High, Medium, Low)

SL: $\quad$ selection line (HFI, LFI)

time: $\quad 4$-wk intervals, for feed intake, BW, and milk production data, four occasions per cow for milk fatty acid composition and body condition scoring.

period: before or after parturition

Values shown in the text are least squares means \pm standard error of the means, unless otherwise stated.

\section{RESULTS}

\section{Feed Intake}

The effect of treatment on DMI is shown in Table 2. Due to high consumption of offered rations during the dry period, DMI corresponded well with the experimental design (Figure 1). The large differences in offered rations between the treatments gave rise to a marked effect of treatment in prepartum DMI. The L and M groups increased DMI the 1st wk postpartum, compared to the dry period, but in the H group DMI had not increased at this time. The L group had numerically higher DMI than the other groups during the lactation period, but there were no significant differences between the treatments during the lactation. There was, however, a tendency $(P<0.07)$ for an interaction between treatment and time. The DMI was not significantly affected by selection line in lactation wk 1 to 12 (Table 2), but the numerical values of weekly mean DMI, shown in Figure 1, diverged between the selection lines after peak lactation.

\section{Response in Body Condition, Body Weight, and Milk Production}

There were no significant differences between the treatment groups or between selection lines in BCS at 
Table 2. Least squares means and F-tests of fixed effects included in the model for DMI, BCS, BW, calculated energy balance (EB), milk yield, composition and milk fat composition respectively. Fixed effects are treatment (T), selection line (SL), time and the interactions between $\mathrm{T} \times \mathrm{SL}, \mathrm{T} \times$ time and $\mathrm{SL} \times$ time. Non significant interactions were excluded from the model except for the interaction of $\mathrm{T} \times$ time.

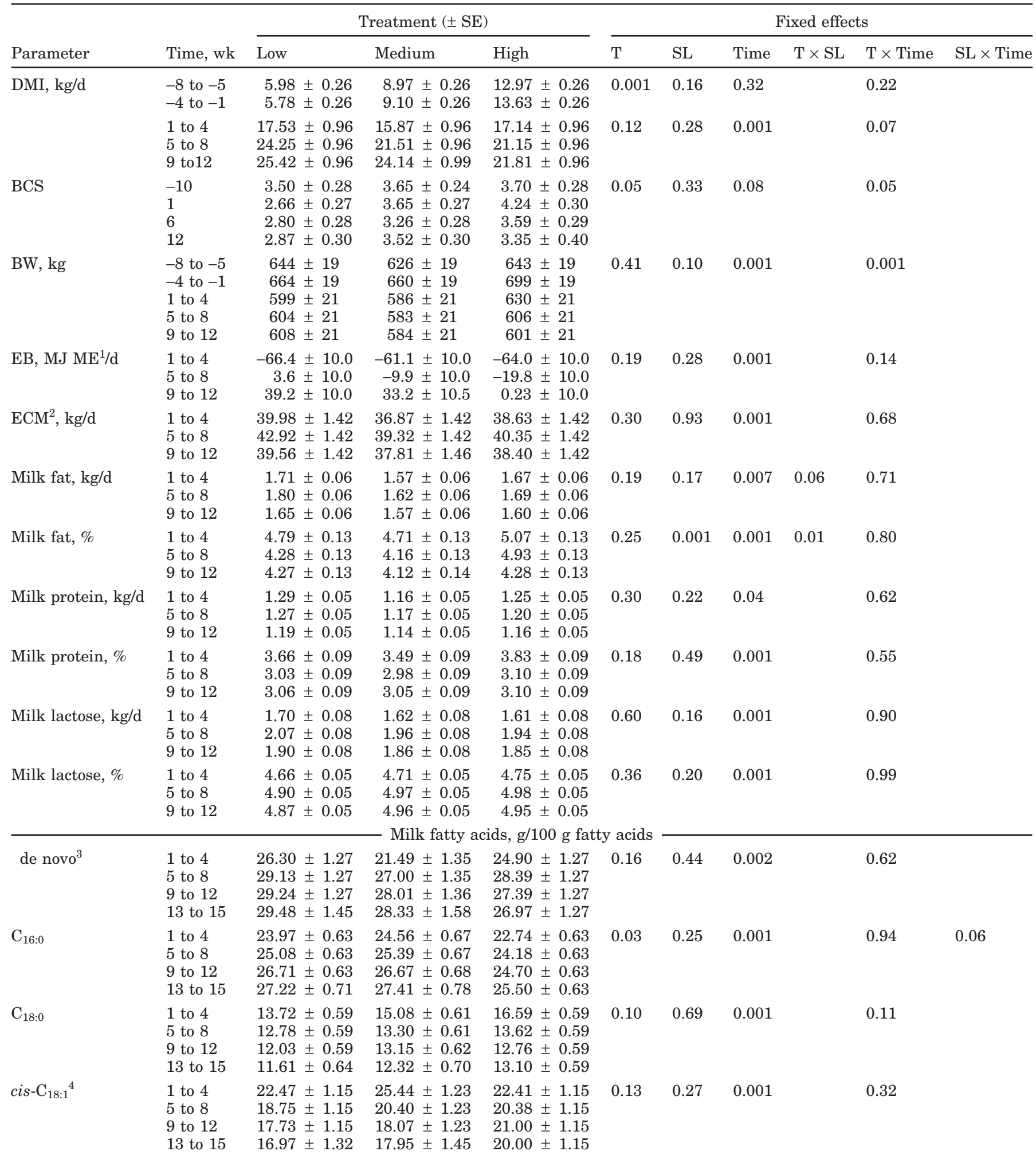

Continued 
Table 2. (Continued).

\begin{tabular}{|c|c|c|c|c|c|c|c|c|c|c|}
\hline Parameter & Time, wk & \multicolumn{3}{|c|}{ Treatment (LS Mean \pm Std Error) } & \multicolumn{6}{|c|}{ Fixed effects } \\
\hline trans $-\mathrm{C}_{18: 1^{5}}$ & $\begin{array}{l}1 \text { to } 4 \\
5 \text { to } 8 \\
9 \text { to } 12 \\
13 \text { to } 15\end{array}$ & $\begin{array}{l}3.20 \pm 0.20 \\
3.44 \pm 0.20 \\
3.50 \pm 0.20 \\
3.51 \pm 0.20\end{array}$ & $\begin{array}{l}3.21 \pm 0.21 \\
3.20 \pm 0.21 \\
3.36 \pm 0.21 \\
3.27 \pm 0.25\end{array}$ & $\begin{array}{l}3.59 \pm 0.20 \\
3.09 \pm 0.20 \\
3.41 \pm 0.20 \\
3.20 \pm 0.20\end{array}$ & 0.63 & 0.90 & 0.72 & & 0.56 & \\
\hline $\mathrm{C}_{18: 2}$ & $\begin{array}{l}1 \text { to } 4 \\
5 \text { to } 8 \\
9 \text { to } 12 \\
13 \text { to } 15\end{array}$ & $\begin{array}{l}1.75 \pm 0.06 \\
2.59 \pm 0.06 \\
1.57 \pm 0.06 \\
1.68 \pm 0.07\end{array}$ & $\begin{array}{l}1.62 \pm 0.07 \\
1.54 \pm 0.07 \\
1.43 \pm 0.07 \\
1.40 \pm 0.08\end{array}$ & $\begin{array}{l}1.53 \pm 0.06 \\
1.45 \pm 0.06 \\
1.55 \pm 0.06 \\
1.58 \pm 0.06\end{array}$ & 0.07 & 0.177 & 0.061 & & 0.24 & 0.08 \\
\hline $\mathrm{C}_{18: 3}$ & $\begin{array}{l}1 \text { to } 4 \\
5 \text { to } 8 \\
9 \text { to } 12 \\
13 \text { to } 15\end{array}$ & $\begin{array}{l}0.61 \pm 0.05 \\
0.56 \pm 0.05 \\
0.59 \pm 0.05 \\
0.67 \pm 0.05\end{array}$ & $\begin{array}{l}0.56 \pm 0.05 \\
0.54 \pm 0.05 \\
0.52 \pm 0.05 \\
0.56 \pm 0.06\end{array}$ & $\begin{array}{l}0.61 \pm 0.05 \\
0.50 \pm 0.05 \\
0.58 \pm 0.05 \\
0.63 \pm 0.05\end{array}$ & 0.31 & 0.44 & 0.10 & & 0.83 & \\
\hline CLA & $\begin{array}{l}1 \text { to } 4 \\
5 \text { to } 8 \\
9 \text { to } 12 \\
13 \text { to } 15\end{array}$ & $\begin{array}{l}0.28 \pm 0.04 \\
0.29 \pm 0.04 \\
0.31 \pm 0.04 \\
0.34 \pm 0.04\end{array}$ & $\begin{array}{l}0.26 \pm 0.04 \\
0.28 \pm 0.04 \\
0.28 \pm 0.04 \\
0.25 \pm 0.04\end{array}$ & $\begin{array}{l}0.25 \pm 0.04 \\
0.27 \pm 0.04 \\
0.30 \pm 0.04 \\
0.42 \pm 0.04\end{array}$ & 0.68 & 0.61 & 0.11 & & 0.44 & 0.06 \\
\hline
\end{tabular}

\footnotetext{
${ }^{1} \mathrm{ME}=$ Metabolizable energy.

${ }^{2} \mathrm{ECM}=$ Energy corrected milk.

${ }^{3}$ de novo $=$ Sum of $\mathrm{C}_{4: 0}, \mathrm{C}_{6: 0}, \mathrm{C}_{8: 0}, \mathrm{C}_{10: 0}, \mathrm{C}_{12: 0}$, and $\mathrm{C}_{14: 0}$.

${ }^{4}$ cis $-\mathrm{C}_{18: 1}=$ Sum of cis-9- $\mathrm{C}_{18: 1}$, cis-11- $\mathrm{C}_{18: 1}$, cis-12- $\mathrm{C}_{18: 1}$, cis-13- $\mathrm{C}_{18: 1}$, trans-13- $\mathrm{C}_{18: 1}$, trans-14- $\mathrm{C}_{18: 1}$, and trans-15- $\mathrm{C}_{18: 1}$.

${ }^{5}$ trans $-\mathrm{C}_{18: 1}=$ Sum of all trans isomers from trans $-4-\mathrm{C}_{18: 1}$ to trans $-15-\mathrm{C}_{18: 1}$.
}

the time when cows were dried off from the previous lactation. The treatment groups diverged in BCS during the dry period and $1 \mathrm{wk}$ after parturition the L group had significantly lower BCS than the M $(P<0.03)$ or $\mathrm{H}(P<0.001)$ group. The $\mathrm{H}$ fed group decreased in BCS score during the first $6 \mathrm{wk}$ of the lactation $(P<0.003)$ while the numerical changes in BCS in the M $(P<$ $0.1)$ and $\mathrm{L}(P<0.4)$ cows during this period were nonsignificant. The L group still had numerically lower BCS than the other two groups at the end of the experiment but these values did not differ significantly.

The average BW of cows $8 \mathrm{wk}$ before parturition was $622 \pm 54 \mathrm{~kg}$ (mean $\pm \mathrm{SD})$, and there were no differences between the treatment groups in BW at this time. Changes in BW are shown in Table 2 and Figure 1. There was a significant $(P<0.001)$ overall increase in BW during the dry period. L cows increased by $33 \pm 9$ $\mathrm{kg}$. The corresponding values for $\mathrm{M}$ and $\mathrm{H}$ cows were $65 \pm 9 \mathrm{~kg}$ and $96 \pm 9 \mathrm{~kg}$ (Model 2), and these changes were significant between all three groups $(P<0.03$ to 0.001 ). All groups averaged $73 \pm 20 \mathrm{~kg}$ ( \pm SD) BW loss, between the week before and the week after parturition, mainly reflecting the weight of fetal tissues and fluid. The H group thereafter continued to lose BW, primarily during the 2 nd to 4 th wk after parturition. The difference in BW between lactation wk 1 and 12 was $-50 \pm$ $11 \mathrm{~kg}$ in the $\mathrm{H}$ group while the two other groups did not change significantly in BW during this period. Numerical values do, however, indicate that the $\mathrm{L}$ group increased their BW during the lactation period (Figure
1). There was no overall effect of treatment or selection line on BW, but there was a tendency $(P<0.10)$ towards higher BW, $27 \pm 16 \mathrm{~kg}$, in LFI cows. There were no changes in BW between the 2nd and 3rd mo of the lactation (wk 5 to 12).

Milk production is shown in Table 2 and Figures 2 and 3. Yield of ECM was affected by time, and the highest yields were found during the second month of the lactation (Table 2, Figure 2). There were no differences in ECM between treatments or selection line. Milk fat concentration and milk protein concentration decreased, while lactose increased during the first month of the lactation. Milk fat concentration for each selection line is shown in Figure 3. The average milk fat concentration during the first $12 \mathrm{wk}$ of the lactation was $4.7 \pm 0.07 \%$ in HFI cows and $4.2 \pm 0.07 \%$ in LFI cows $(P<0.001)$. There was an interaction between selection line and treatment, mainly due to low milk fat content in LFI cows that received the M dry period treatment. The average milk fat concentration during the first $12 \mathrm{wk}$ of the lactation was $3.9 \pm 0.13 \%$ for this group, and that was lower than in all other combinations of treatment and selection line $(P<0.001)$ except for LFI cows in the L group.

Milk fat yield did not differ between the selection lines but, like in milk fat concentration, there was an interaction between selection line and time (Table 2, Figure 3). The interaction was due to differences between selection lines receiving the same treatment and also within selection line in different treatment groups. 

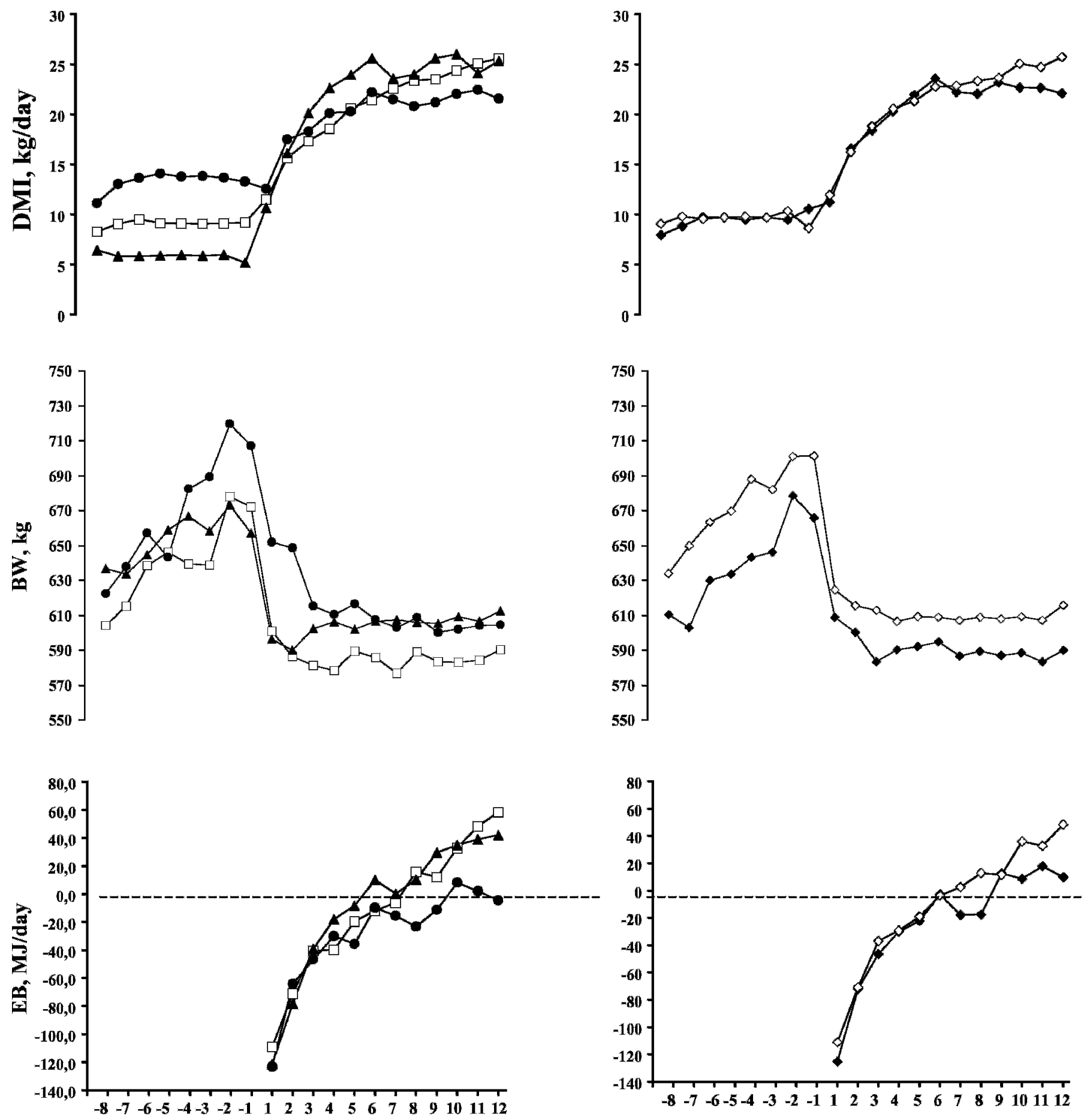

weeks relative to parturition

Figure 1. Mean values of dry matter intake (DMI) and body weight (BW) during the dry period (8 wk) and the first 12 wk of the lactation, and calculated energy balance (EB) during the first 12 wk of the lactation. The curves represent cows that were treated with high (-), medium $(\square)$ or low $(\mathbf{\Lambda})$ dry matter intake of a TMR during the dry period and curves in the right column represent cows from two different selection lines that are bred for high $(\diamond)$ or low $(\diamond)$ milk fat content. 

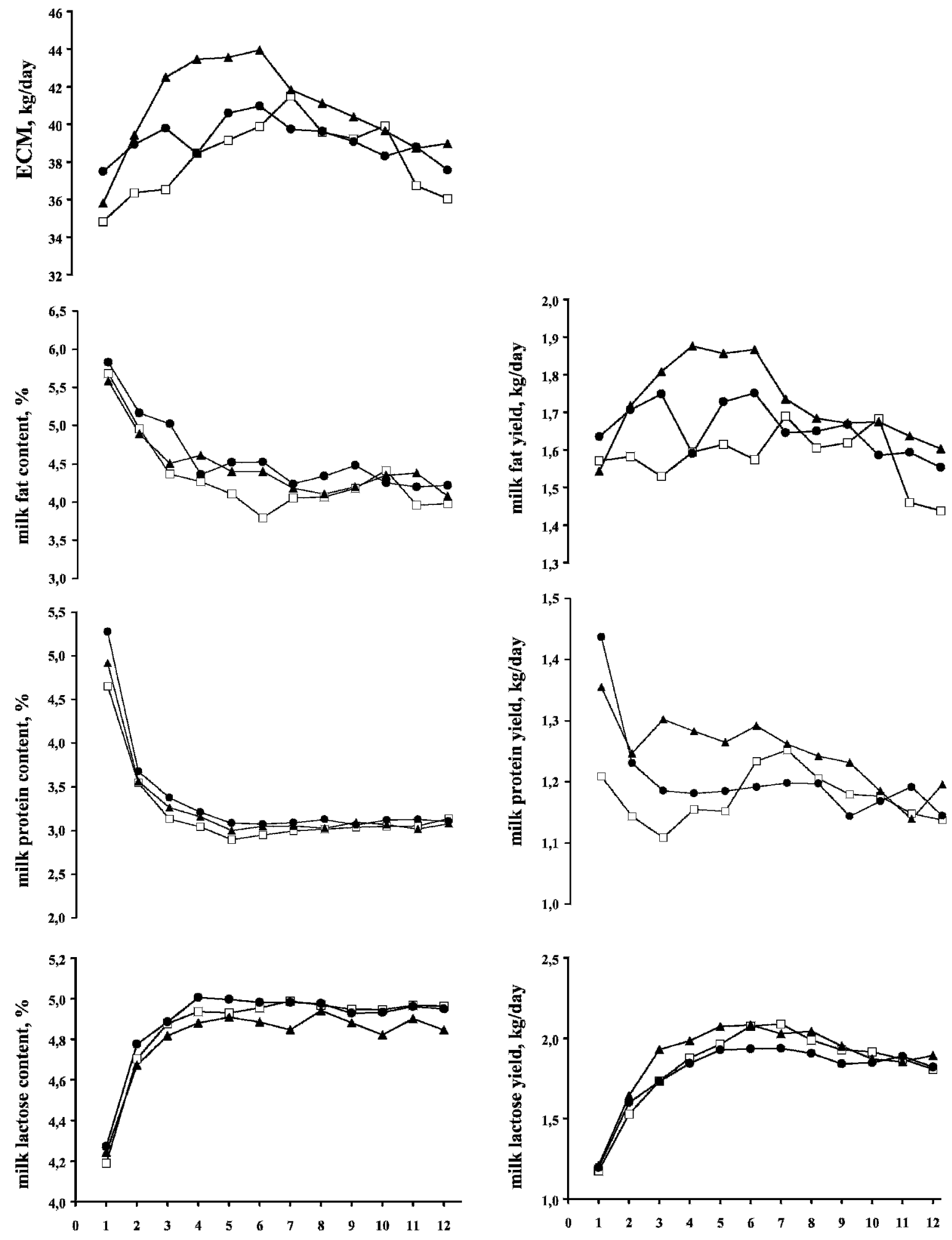

\section{weeks relative to parturition}

Figure 2. Mean values of energy corrected milk (ECM), milk content of fat, protein and lactose and daily yields of fat protein and lactose in milk. The curves represent cows that were treated with high $(\bullet)$, medium ( $\square$ ) or low (A) dry matter intake of a TMR during the dry period. 

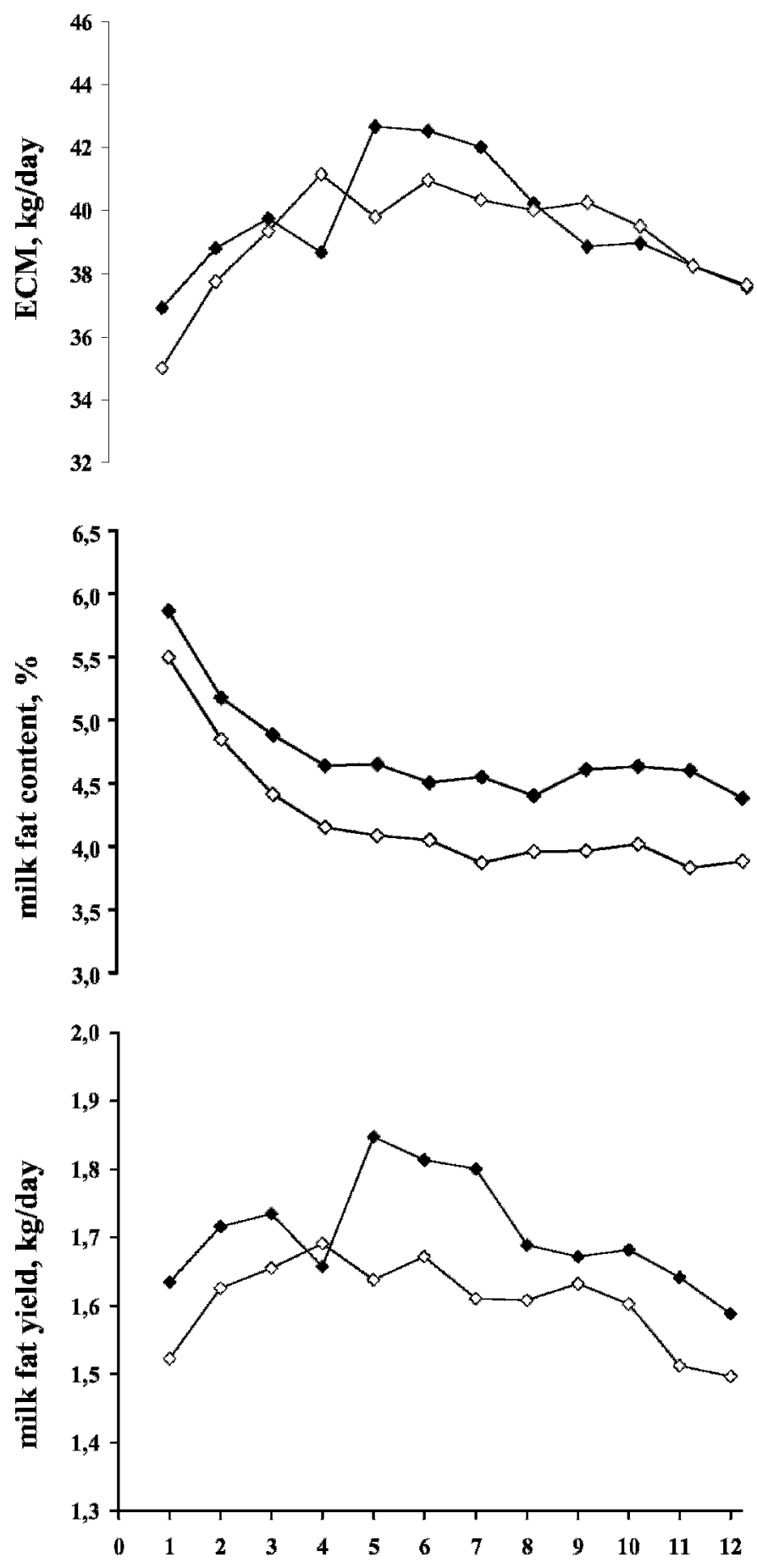

\section{week relative to parturition}

Figure 3. Mean values of energy corrected milk (ECM), milk fat content, milk fat yield and milk lactose content. The curves represent cows from two different selection lines that are bred for high $(\diamond)$ or low $(\diamond)$ milk fat content.
The HFI cows that received the $\mathrm{L}$ treatment produced less milk fat than HFI cows on the $\mathrm{H} \operatorname{diet}(P<0.024)$, and it also tended to be lower than that of HFI cows in group $\mathrm{M}(P<0.08)$. Likewise, LFI cows tended to produce more fat on the $\mathrm{H}$ than on the $\mathrm{M}$ treatment $(P<$ 0.071), and HFI cows produced more fat than LFI cows within the $\mathrm{L}$ treatment group $(P<0.023)$. Beyond these differences in milk fat production there were no effects on concentrations or yields of milk fat, milk protein or lactose by treatment or selection line.

\section{Milk Fat Composition}

Milk fat composition for the different treatments is shown in Figure 4 and difference between selection lines is shown in Figure 5. The composition of milk fat changed over time. $\mathrm{C}_{4}$ to $\mathrm{C}_{14}$ de novo synthesized fatty acids increased between the 1st and 2 nd mo of the lactation but there were no differences between treatments or selection line. All cows showed an increased content of $\mathrm{C}_{16: 0}$ in milk fat as the lactation went on. The $\mathrm{H}$ group had lower $\mathrm{C}_{16: 0}$ than the other groups during the whole lactation period. Furthermore, HFI cows increased in $\mathrm{C}_{16: 0}$ sooner than LFI cows did and at the last milk fatty acid analysis $\mathrm{C}_{16: 0}$ was higher in HFI cows than in LFI cows $(P<0.03)$. The milk fat content of $\mathrm{C}_{18: 0}$ decreased over time, and the $\mathrm{H}$ group showed higher milk fat content of $\mathrm{C}_{18: 0}$ than the $\mathrm{L}$ group $(P<0.02)$ over the whole lactation period. There was no effect of selection line on $\mathrm{C}_{18: 0}$ content. $\mathrm{Cis}-\mathrm{C}_{18: 1}-$ fatty acids in milk fat decreased between the first and second 4 -wk period of the lactation $(P<0.001)$. There were no effects of treatment or selection line on cis- $\mathrm{C}_{18: 1}$-fatty acids and trans- $\mathrm{C}_{18: 1}$-fatty acids were not affected by any of the factors included in the model. LFI cows had higher $\mathrm{C}_{18: 2}$ content than HFI cows in the beginning of the lactation $(P<0.01)$. The $\mathrm{L}$ group had higher $\mathrm{C}_{18: 2}$ content in milk fat than the M group $(P<0.05)$ and tended to have higher fat content than the $\mathrm{H}$ group $(P<0.06)$ during the whole experiment. Furthermore, there was a tendency for decreased $\mathrm{C}_{18: 2}$ content as the lactation went on $(P<0.06)$. The milk fat content of $\mathrm{C}_{18: 3}$ was not affected by any of the factors included in the model. Conjugated linoleic acids (CLA) in milk were influenced by time and also by an interaction between time and selection line $(P<0.05)$, which can be largely explained by an increase over time found in HFI cows. This increase came at the end of the experiment $(P<$ 0.003 ) and at this point CLA also tended to be higher in HFI than LFI cows $(P<0.06)$, and there was also an overall increase between the first and last samples in CLA content $(P<0.02)$. 

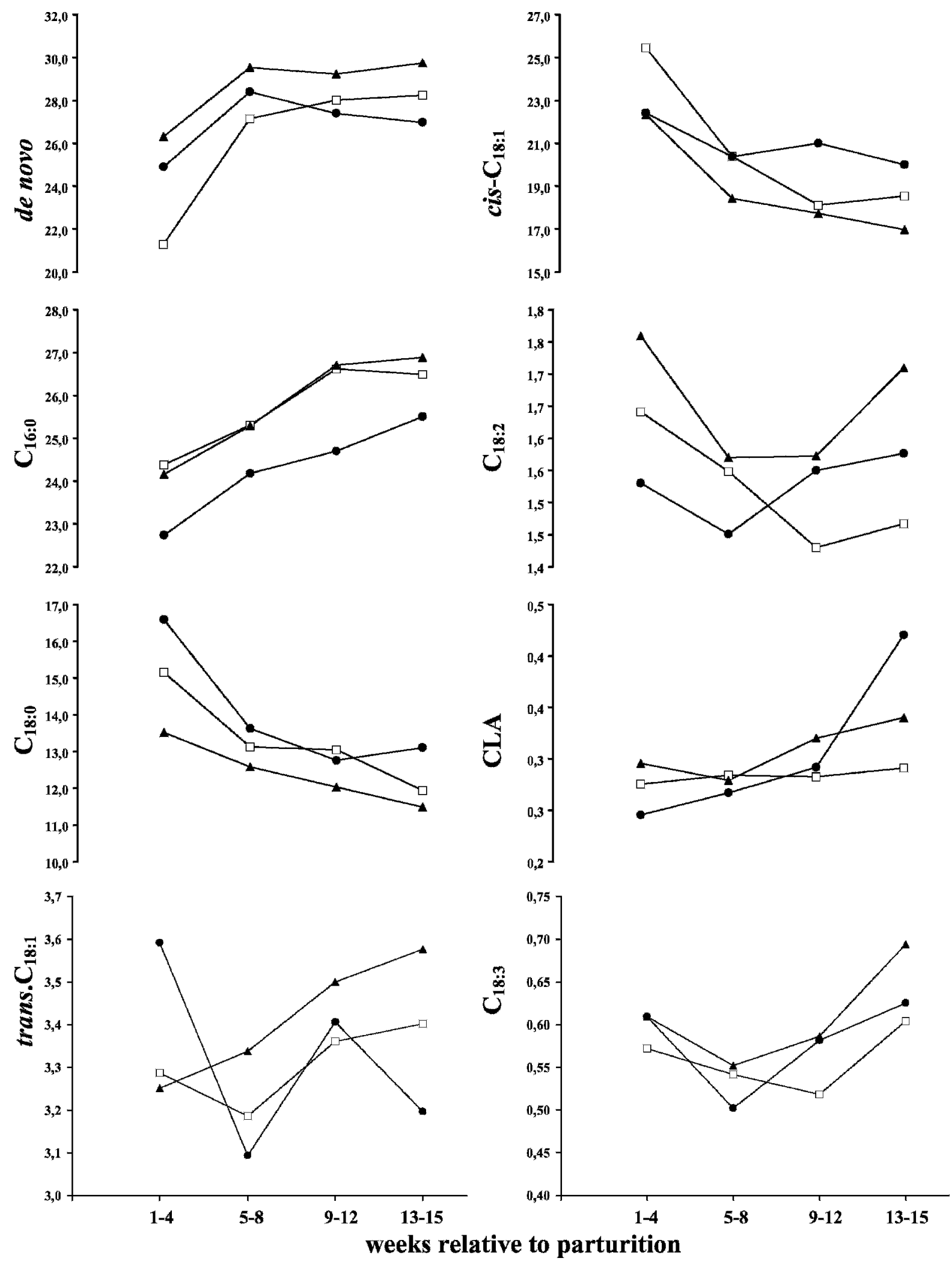

Figure 4. Mean values of milk fatty acid content (g/100 g fatty acids) in morning milk obtained on four occasions evenly distributed for each animal across the first $15 \mathrm{wk}$ of the lactation. The curves represent cows that were treated with high $(\bullet)$, medium ( $\square)$ or low (A) dry matter intake of a TMR during the dry period. 


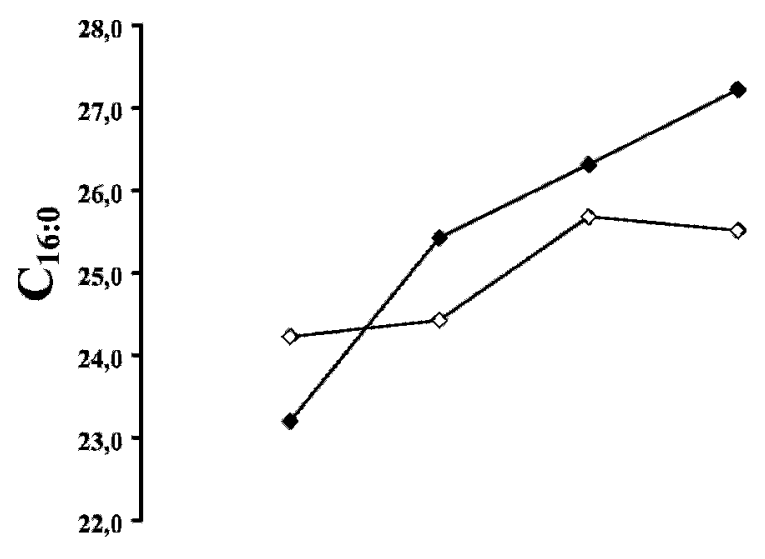

\section{Energy balance}

The calculated EB after parturition is shown in Table 2 and Figure 1. The statistical analyses showed neither an effect of treatment or selection line, but the weekly means in Figure 1 indicate that the $\mathrm{L}$ group was the first to reach positive $\mathrm{EB}$, followed by the $\mathrm{M}$ and last by the $\mathrm{H}$ group. Furthermore, Figure 1 indicates that HFI cows remained in negative EB longer than LFI cows.

\section{DISCUSSION}

\section{Effects in the Dry Period}

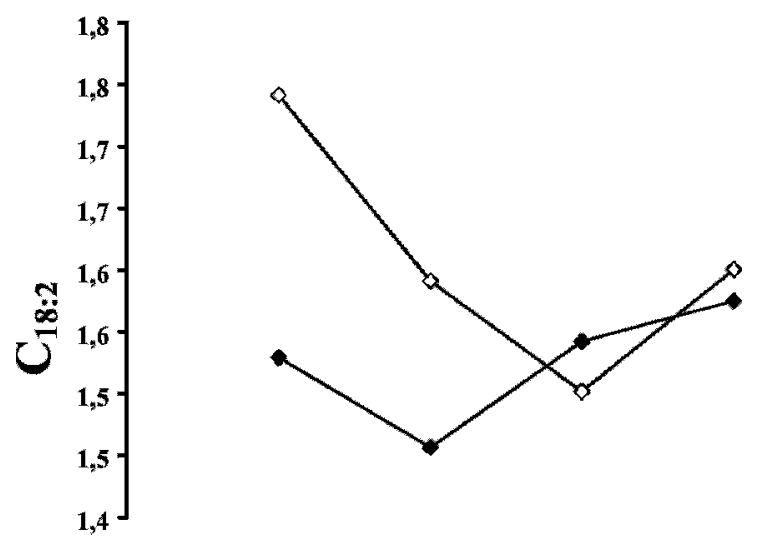

Our intention to create groups of cows with different BCS at parturition was successfully achieved. The three levels of TMR during the dry period generated differences between the groups in BW gain as well as in BCS during the dry period. The increase in BW of $33 \pm 9 \mathrm{~kg}$ during the dry period in the $\mathrm{L}$ group is likely to represent a decrease in body mass, assuming that the weight of fetal tissues and fluid increase with about $45 \mathrm{~kg}$ during an 8-wk dry period (Klop et al., 1998). In accordance with this L cows lost more than one unit in BCS on the five-graded scale used, while there was no change in BCS in the M group, and $\mathrm{H}$ cows gained almost one unit during the dry period. The $\mathrm{H}$ group, that was offered $14.5 \mathrm{~kg} \mathrm{DM}$ during the dry period, consumed on average $13.6 \mathrm{~kg} \mathrm{DM} / \mathrm{d}$ during the last 4 wk before parturition, which was equivalent of $2 \%$ of their BW. Since feed refusals were almost $10 \%$ of the ration offered, the $\mathrm{H}$ treatment may be considered as ad libitum. Similar DMI in multiparous cows during the dry period has been reported by Kunz and Blum (1985). The DMI has been reported to decrease, to a greater or lesser extent, as cows approach parturition (Grummer, 1995; Dann et al., 1999; Ingvartsen and Andersen, 2000; Dewhurst et al., 2001). Physical limitations, due to fetal growth, have been suggested as an explanation for decreased DMI near the time of parturition (Ingvartsen et al., 1992). The cows in the present study only showed a small, if any, reduction in feed intake as they approached parturition. The weekly mean values, shown in Figure 1, indicate that there may have been a reduction in DMI in the $\mathrm{H}$ group during the last 2 wk before parturition, and some individuals in the $\mathrm{H}$ group demonstrated distinctly lower DMI during the last days before parturition (data not shown). However, the statistical analyses did not show lower DMI during the second half compared to the first half of the dry period. The fact that DMI was well maintained even close to parturition in this study calls into question whether there really are mechanical limitations in DMI during the dry period. It is more likely that DMI is adjusted to EB by metabolic or hormonal 
factors. Possible candidates for mediating EB are insulin and leptin that have been shown to affect appetite in monogastrics (McGowan et al., 1992; Barrachina et al., 1997; Barb et al., 1998; Larsson et al., 1998) and ruminants (Morrison et al., 2001). Insulin and leptin data from the present study are presented elsewhere (Holtenius et al., 2002). Earlier studies (Åkerlind et al., 1999) have suggested that LFI cows have higher DMI capacity than HFI cows. There were no significant differences in DMI between the selection lines during the dry period in this study, but LFI cows showed numerically higher $\mathrm{DMI}$ in the $\mathrm{H}$ fed group, $13.7 \pm 1.7$ versus $12.9 \pm 2.4$ (mean $\pm \mathrm{SD}$ ). It is not surprising that there were no differences between the selection lines in DMI in the L and $\mathrm{M}$ groups since these groups were fed restricted amounts.

\section{Effects in wk 1 to 4}

The DMI was fairly equal between the three treatment groups during the critical $4 \mathrm{wk}$ at the beginning of the lactation, which implies that neither differences in fat deposit nor the extent of adaptation to high DMI necessarily influences feed intake capacity. It is reasonable to assume that, during the dry period, rumen short chain fatty acid (SCFA) production was related to feeding intensity. It is generally accepted that SCFA stimulate rumen papilla growth, which in turn facilitate rumen absorption (Dirksen et al., 1985) and may influence DMI. However, Andersen et al. (1999) did not find any postpartum differences in the absorptive capacity of rumen epithelium, rumen $\mathrm{pH}$ or DMI between cows that received concentrate based versus roughage-based diets during the dry period. On basis of the similarity in DMI between the groups in early lactation and the results by Andersen et al. (1999), it may be concluded that the treatments in the present study did not create any differences in rumen absorption that influenced DMI.

The only indication of differences between treatments in DMI during the first $4 \mathrm{wk}$ of the lactation was noted during the 1st wk postpartum, when the $\mathrm{H}$ group remained at the same DMI as before parturition while the other two groups increased their intake, most rapidly in the L group (Figure 1). Despite similar DMI and yield of ECM between the groups in early lactation the $\mathrm{H}$ group had considerably higher mobilization of body tissues. In another trial, it was observed that cows with high BCS at calving and fed ad lib after calving lost more BW and BCS than thin cows, despite the fact that they had the same levels of plasma NEFA and the same decrease in the size of adipocytes between wk 1 and 8 of lactation (Chilliard, 1992). It is therefore assumed that the $\mathrm{H}$ cows were less efficient in energy utilization than the other two groups during the first 4 wk of the lactation. The total amount of energy available from feed and mobilized body reserves was higher in $\mathrm{H}$ cows than in $\mathrm{L}$ and $\mathrm{M}$ cows, but the $\mathrm{H}$ cows did not show a correspondingly higher energy output in milk. This difference is interesting and requires further research in order to provide a mechanistic explanation.

Waltner et al. (1993) and Putnam and Varga (1998) have reported results that indicate the influence of BCS at parturition on milk yield at the onset of the lactation. However, in the present study there was no clear relationship between BCS and milk yield during the first month of the lactation. Our result is in agreement with data reported by Chilliard (1992), in which the effect of BCS at calving on milk yield was high when cows were restricted after calving but not when cows were fed ad lib. The cows in the $\mathrm{N}$ and $\mathrm{H}$ groups lost about 3.7 and $6.4 \%$, respectively, in average weekly BW during the first 4 wk of the lactation. The L cows showed a small numerical increase in BW during this period. Dann et al. (1999) reported 11 to $14 \%$ BW reduction during the first 9 wk of the lactation for cows fed different TMR mixes during the dry period and lactation. The cows in their study had similar milk yields to the cows in the present study, and a DMI/kg during the dry period that was comparable to that of $\mathrm{H}$ cows in the present study. The lower BW loss during the lactation in the present study compared to Dann et al. (1999) can probably be explained by higher DMI postpartum. Chilliard (1992) reported a $5 \% \mathrm{BW}$ loss during the first 8 wk postpartum in cows with similar DMI as in the present study.

\section{Effects in wk 5 to 12}

The difference in DMI between $\mathrm{H}$ and the other groups first occurred around wk 6 and remained until wk 12. These differences were most pronounced at the end of the experiment (Figure 1, Table 2) and in combination with similar milk yields, this caused differences in calculated EB (Figure 1). It has often been stated that if the dry period feeding allows the cow to reach a high body condition at parturition the DMI intake in the following lactation will be negatively affected (Garnsworthy, 1988). It has been suggested that mobilization of body tissues has a limiting effects on appetite (Rukkwamsuk et al., 1999) but since weight loss mainly occurred during the first $4 \mathrm{wk}$ of the lactation in the present study, it is unlikely that this was influencing appetite after lactation wk 6. However, since DMI was higher in wk 5 to 12 than during wk 1 to 4 of the lactation it cannot be excluded that ruminal fill also was higher during in wk 5 to 12 , and that this concealed a further decrease in the live weight due to tissue mobilization, which in turn may have influenced the appetite of the cows. 


\section{Effects on Milk Composition}

Klop et al. (1998) and Holcomb et al. (2001) have reported 0.2 to 0.8 percentage units higher milk fat content during the first 5 wk of the lactation for cows fed ad libitum, compared to those on a restricted diet, during the dry period. In the present study milk fat production was not significantly affected by treatment, but the least squares means were about 0.3 percentage units higher in the $\mathrm{H}$ group than in the other groups in lactation wk 1 to 4 . Therefore, it is possible that a high dry period feeding intensity may increase milk fat content in early lactation. Furthermore, Klop et al. (1998) reported lower milk protein content in lactation wk 1 to 5 in cows that received ad libitum compared to restricted feeding during the dry period. Again, there was no overall effect by treatment on milk protein content in the present study and least squares means were higher in the $\mathrm{H}$ group, which is in contrast to the results by Klop et al. (1998) but agree with results reported by Chilliard (1992).

The $\mathrm{C}_{4}$ to $\mathrm{C}_{14}$ and part of the $\mathrm{C}_{16}$ fatty acids in milk fat are known to be de novo synthesized in the mammary gland (Garton, 1963). Remaining $\mathrm{C}_{16}$ and long chain fatty acids (LCFA) can originate either from dietary fat or adipose tissue. In the present study there were no differences between the treatments in $\mathrm{C}_{4}$ to $\mathrm{C}_{14}$ de novo fatty acids but the $\mathrm{H}$ group showed lower content of $\mathrm{C}_{16: 0}$ in milk fat along with reciprocally higher $\mathrm{C}_{18: 0}$ at the beginning of the lactation. It may be hypothesized that these differences occurred due to a higher supply of LCFA of body origin in the $\mathrm{H}$ group than in the other groups. The content of $\mathrm{C}_{18: 2}$ in milk fat has been connected to occurrence of off-flavor in milk (Barrefors et al., 1995). Since there was a tendency towards higher $\mathrm{C}_{18: 2}$ in milk from the L treated cows, it may be hypothesized that off-flavor was more likely to occur in this group than in the other groups (Figure 4). The fact that there was no treatment effect on the unsaturated LCFA apart from $\mathrm{C}_{18: 2}$ show that their formation was regulated by other factors than feed intake, adiposity and EB in the present study.

\section{Differences Between the Selection Lines}

Previous studies on the selection lines used in this study have indicated a higher DMI capacity and higher BW in LFI cows (Åkerlind et al., 1999). In the present study there were no overall differences in DMI between the selection lines. However, in the H group LFI cows had numerically higher DMI than HFI cows during wk 7 to 12 , which also probably contributed to the slightly lower EB among HFI cows (Figure 1). Furthermore, as shown in Figure 1, the difference between the selection lines in DMI, that arouse in lactation wk 7, increased with time and was $16 \%$ higher in LFI cows in lactation wk 12 . These results indicate that DMI capacity may diverge between the selection lines after peak production. Furthermore, the difference in BW between the selection lines in this study support the previous findings by Åkerlind et al. (1999), that LFI cows tend to have higher BW than HFI.

The difference between the selection lines in milk fat content was expected, but the interaction between selection line and treatment seen in milk fat production is interesting, since it indicates that there may be differences between the selection lines in the prioritization of nutrients for milk production. The fact that the selection lines showed differences in the response to treatments indicates that animals from different populations may vary in their response to dry period management and that this can influence milk composition. One example is the tendency towards higher content of $\mathrm{C}_{18: 2}$ in milk fat from LFI cows (Figure 5), which indicates that this selection line may be more disposed for occurrence of off-flavor in milk (Barrefors et al., 1995). This hypothesis needs however to be confirmed by measurements of sensorial taste, because differences in percentage of $\mathrm{C}_{18: 2}$ were of small extent.

\section{CONCLUSIONS}

The present study supports the suggestion of Dewhurst et al. (2000), that cows in early lactation have a potential to compensate for low nutrient intake during the dry period by a high intake in early lactation, if they are offered a diet with high energy density and high palatability. The results in this study also point out that a high DMI during the dry period may negatively effect overall production conditions, since the feed costs during the dry period are not necessarily connected to a correspondingly high milk yield postpartum. Fat deposition caused by high feed intake during the dry period is related to prolonged negative EB, which in turn may be detrimental to reproductive functions. The differences in DMI 6 to 12 wk postpartum could not be explained by differences in milk yield or mobilization of body tissues. There was no evidence for differences in milk yield at the onset of lactation between cows fed ad libitum compared to those on restricted rations of a high quality TMR during the dry period, but milk composition is likely to be affected. Milk fat concentration as well as milk fat content of $\mathrm{C}_{18: 0}$ were increased by high DMI during the dry period. Cows with genetic merit for different milk fat content did not respond with significant differences in BW, DMI or milk yield but the HFI cows showed higher milk fat content, milk fat yield and different content of $\mathrm{C}_{16: 0}, \mathrm{C}_{18: 2}$, and CLA than LFI cows in this study. 


\section{ACKNOWLEDGMENTS}

Financial support from the Swedish Farmer's Foundation for Agricultural Research (No. 9930028 and 9930044) and The Swedish Council for Forestry and Agricultural Research (No. 30.0590/98) is gratefully acknowledged.

\section{REFERENCES}

Åkerlind, M., M. Emanuelsson., K. Dahlborn, and K. Holtenius. 1999. Glucose challenge in early lactating dairy cows selected for high or low milk-fat concentration. Anim. Sci. 68(4):717-722.

Andersen, J. B., J. Sehested, and K. L. Ingvartsen. 1999. Effect of dry cow feeding strategy on rumen $\mathrm{pH}$, concentration of volatile fatty acids and rumen epithelium development. Acta Agric. Scand., Sect A. Anim. Sci. 49:149-155.

Barb, C. R., X. Yan, M. J. Azain, R. R. Kraeling, G. B. Rampacek, and T. G. Ramsey. 1998. Recombinant porcine leptin reduces feed intake and stimulates growth hormone secretion in swine. Domest. Anim. Endocrinol. 15:77-86.

Barrachina, M. D., V. Martinez, J. Y. Wei, and Y. Taché. 1997. Leptininduced decrease in food intake is not associated with changes in gastric emptying in lean mice. Am. J. Physiol. 272:R1007-R1011.

Barrefors, P., K. Granelli, L.-A. Appelqvist, and L. Bjoerck. 1995. Chemical characterization of raw milk samples with and without oxidative off-flavor. J. Dairy Sci. 78:2691-2699.

Chilliard, Y. 1992. Physiological constraints to milk production: factors which determine nutrient partitioning, lactation persistency and mobilization of body reserves. World Rev. Anim. Prod. 19-26.

Dann, H. M., G. A. Varga, and D. E. Putnam. 1999. Improving energy supply to late gestation and early postpartum dairy cows. J. Dairy Sci. 82:1765-1778.

Dewhurst, R. J., J. M. Moorby, M. S. Dhanoa, and W. J. Fishert. 2001. Effects of level of concentrate feeding during the second gestation of Holstein-Friesian dairy cows. 1. Feed intake and milk production. J. Dairy Sci. 85:169-177.

Dewhurst, R. J., J. M. Moorby, M. S. Dhanoa, R. T. Evans, and W. J. Fisher. 2000. Effects of altering energy and protein supply to dairy cows during the dry period. 1. Intake, body condition and milk production. J. Dairy Sci. 83:1782-1794.

Dirksen, G. U., H. G. Liebich, and E. Mayer. 1985. Adaptive changes of the ruminal mucosa and their functional and clinical significance. Bovine Pract. 20:116-120.

Garnsworthy, P. C. 1988. The effect of energy reserves at calving on performance of dairy cows. Pages 157-170 in Nutrition and Lactation in the Dairy Cow. P. C. Garnsworthy, ed. Butterworths, London.

Garton, G. A. 1963. The composition and biosynthesis of milk lipids. J Lipid Res. 4:237.

Gillund, P., O. Reksen, K. Karlberg, Å. T. Randby, I. Engeland, and B. Lutnæs. 1999. Utprøvning av en holdvurderingsmetode på NRFkyr. Norsk Veterinærtidsskrift, 111(10):623-632.

Goff, J. P., and R. L. Horst. 1997. Physiological changes at parturition and their relationship to metabolic disorders. J. Dairy Sci. 80:1260-1268.
Grummer, R. R. 1995. Impact of changes in organic nutrient metabolism on feeding the transition dairy cow. J Anim. Sci. 73, 28202833.

Holcomb, C. S., H. H. Van Horn, H. H. Head, M. B. Hall, and C. J. Wilcox. 2001. Effects of prepartum dry matter intake and forage percentage on postpartum performance of lactating dairy cows. J Dairy Sci. 84:2051-2058.

Holtenius, K., S. Agenäs, C. Delavaud, and Y. Chilliard. 2002. Effects of feeding intensity during the dry period. 2. Metabolic and hormonal responses. [MS 02-0142].

Ingvartsen, K. L., and J. B. Andersen. 2000. Symposium: Dry matter intake of lactating dairy cattle. Integration of metabolism and intake regulation: A review focusing on periparturient animals. J. Dairy Sci. 83:1573-1597.

Ingvartsen, K. L., H. R. Andersen, and J. Foldager. 1992. Effect of sex and pregnancy on feed intake capacity of growing cattle. Acta Agric. Scand., Sect. A, Anim. Sci. 42:40-46.

Jansson, L. 1993. Vad händer vid urval för hög respektive låg mjölkfetthalt? SLU Info Rapporter, Allmänt. Swedish Univ. Agric. Sci., Uppsala, Sweden.

Klop, A., G. A. L. Meijer ,and T. A. M. Kruip. 1998. Energy intake during the dry period and energy balance in dairy cows around calving. 10th Int. Conf. Prod. Diseases Farm Anim. 1998. Abstr.

Kunz, P. L., and J. W. Blum. 1985. Effects of different energy intakes before and after calving on food intake, performance and blood hormones and metabolites in dairy cows. Anim. Prod. 40:219-231.

Larsson, H., S. Elmstahl, G. Berglund, and B. Ahren. 1998. Evidence for leptin regulation of food intake in humans. J. Clin. Endocrinol. Metab. 83:4382-4385.

McGowan, M. K., K. M. Andrews, and S. P. Grossman. 1992. Chronic intrahypothalamic infusions of insulin or insulin antibodies alter body weight and food intake in the rat. Physiol. Behav. 51:753-766.

Morrison, C. D., J. A. Daniel, B. J. Holmberg, J. Djiane, N. Raver, A. Gertler, and D. H. Keisler. 2001. Central infusion of leptin into well-fed and undernourished ewe lambs: effects on feed intake and serum concentrations of growth hormone and luteinizing hormone. J Endocrinol. 168:317-324.

Nourooz-Zadeh, J., and L.-A. Appelqvist. 1988. Cholesterol oxides in Swedish foods and food ingredients: Milk powder products. J. Food Sci. 53:74-79 and 87.

Official Journal of the European Communities. 1984. Determination of crude oils and fat. Method B. No 15.

Putnam, D. E., and G. A. Varga. 1998. Protein density and its influence on metabolite concentration and nitrogen retention by Holstein cows in late gestation. J. Dairy Sci. 81:1608-1618.

Rukkwamsuk, T., T. A. Kruip, and T. Wensing. 1999. Relationship between overfeeding and overconditioning in the dry period and the problems of high producing dairy cows during the postparturient period. Vet. Q. 21:71-77. Review.

SAS User's Guide: Statistics. 1996. SAS/Stat Software. Changes and enhancement through release 6.12. SAS Inst., Inc., Cary, NC.

Spörndly, R. 1999. Fodertabell för idisslare. Rapport 247, Dept. of Anim. Nutr. and Management, Swedish Univ. Agric. Sci., Uppsala, Sweden (in Swedish).

Sukhija, P. S., and D. L. Palmquist. 1988. Rapid method for determination of total fatty-acid content and composition of feedstuffs and feces. J. Agric. Food Chem. 36:1202-1206.

Waltner, S. S., J. P. McNamara, and J. K. Hillers. 1993. Relationships of body condition score to production variables in high producing Holstein dairy cattle. J. Dairy Sci. 76:3410-3419. 